\title{
Development of Learning Devices Based on Realistic Mathematics Approach to Improve Communication Skills and Mathematical Literacy of Torgamba Negeri 5 Middle School Students
}

\author{
Juriah Ardiah Ningsih Daulay ${ }^{1}$ Hasratuddin $^{2} \quad$ Abil Mansyur $^{3}$ \\ University of Medan, Jl. Willem Iskandar Psr. V Medan, Indonesia
}

\begin{abstract}
This research aims to: Analyzing the validity, practicality, and effectiveness of learning tools oriented towards problem-based learning models assisted by macromedia flash that was developed to improve students' mathematical literacy skills. there is an increase in students' mathematical communication skills by using learning devices based on realistic mathematical approaches that were developed in trial I and trial II by $6.74 ; 3$ and there is an increase in students' mathematical literacy skills by using learning devices based on realistic mathematical approaches that were developed in trial I and trial II by 5.68 .

Keywords: Development of Learning Tools, based on Realistic Mathematical Approaches, Communication Skills and Mathematical Literacy

DOI: $10.7176 / \mathrm{JEP} / 11-14-16$

Publication date:May $31^{\text {st }} 2020$

\section{PRELIMINARY}

Learning is one of the most important elements in the implementation of education. The importance of creating quality education means the same as creating quality learning, especially mathematics learning. Mathematics is an important subject for students. This is shown by learning mathematics that starts from elementary to high school. According to Hasratuddin $(2015: 27)$ mathematics is a means or way to find answers to problems faced by humans, a way of using information, using knowledge about shapes and sizes, using knowledge about counting, and the most important thing is to think in humans themselves to see and use relationships.

National Council of Teachers of Mathematics (NCTM) (Hasratuddin, 2015: 35) states that there are abilities that students must achieve in learning mathematics, namely: School mathematics standards include mathematical content and mathematical processes. Standard processes include problem solving, reasoning and proofing, connection, communication, and representation. These process standards together constitute the basic skills and understanding needed by students in the 21 st century. In addition, the mathematics learning goals set by the Ministry of National Education are in line with NCTM (2000: 67) which sets five competencies in mathematics learning: mathematical problem solving (mathematical problem solving), mathematical communication (mathematical communication), mathematical reasoning (mathematical reasoning), mathematical connections (mathematical connections), and mathematical representation (mathematical representation). These skills are high order mathematical thinking skills (high order mathematical thinking) that are important to be developed by students in the mathematics learning process. In this learning goal, communication skills are one of the goals to be achieved. According to NCTM (2000: 60-61), mathematical communication skills need to be present in students so that they can: a) Model the situation verbally, in writing, pictures, graphics, and algebraically, b) Reflect and clarify in thinking about ideas mathematics in various situations. In NCTM (2000: 61) it is also stressed that, "to support the implementation of effective learning, teachers must develop mathematical communication in the classroom so that students feel free to express ideas, ideas, and answers. According to Sumarmo (Hodiyanto, 2017) describe the communication skills that must be built students include communication skills that connect real objects, pictures, tables and diagrams into mathematical ideas and explain mathematical ideas orally or in writing in daily life into mathematical symbols.
\end{abstract}

\section{LITERATURE REVIEW}

According to Kadir (Sri Asnawati, 2017) students communicate mathematical ideas when solving problems, or when conveying the process and results of problem solving are also abilities that can develop higher-level mathematical thinking abilities such as logical, analytical, systematic, critical, creative and productive. In the process of learning mathematics that facilitates the development of these two abilities can develop the potential of thinking optimally.

Based on the explanation above, the importance of communication skills is not relevant to the reality. Because someone is said to have communication skills if students are able to solve mathematical problems by paying attention to the process of finding the answers. Based on the National Council of Teachers of Mathematics 2003 (Supandi, 2017) and NCTM (1989: 214)) states that indicators of mathematical communication skills include "Written text, namely (the ability to understand, interpret, and evaluate mathematical ideas both verbally and in 
the form of other visuals), Drawing, namely (The ability to express mathematical ideas through oral, written, and demonstrate it and describe it visually and in mathematical expressions, that is (The ability to use terms, mathematical notations and their structures for presenting ideas, describing relationships and models of the situation). But in reality students do not show this in their answers. The following are mastery level categories that are guided by (Dikti, 2010: 8-9) the categories of student mastery are as follows:

Table 2.1 Criteria for Initial Capabilities

\begin{tabular}{|c|c|}
\hline Mastery Level & Category \\
\hline$\geq 70 \%$ & High \\
\hline $50 \%-70 \%$ & Is \\
\hline$<50 \%$ & Low \\
\hline
\end{tabular}

Based on observations obtained the average level of student mastery of students' mathematical communication skills is $32.8 \%$. From Table 2.1 it can be concluded that the level of student mastery of students' mathematical communication skills is still in the low category.

The low ability of mathematical literacy can be seen from the questions in the form of PISA. According to Mahdiansyah (Nur Indah, Sitti Mania, Nursalam, 2016), Data from the PISA (Program for International Student Assessment) in 2000, 2003, 2006, 2009 showed results that did not change much at each participation. The average score of mathematics literacy achievement in PISA in 2009, Indonesia only ranked 61 out of 65 participants with an average score of 371 , while the average international score was 496 . PISA itself is an international study program that aims to test literacy achievement, math and science school students aged between 15 years who are nearing the end of compulsory education.

According to the 2013 OECD (Wardono, Rosyida Isnaini, Mulyono, 2018) aspects of content are divided into four parts, namely change and relationship, space and shape, quantity and quantity, and uncertainty of data ). Context components used include personal, work, social and scientific. While the process components include the ability to formulate, apply and interpret mathematical results. The ability of this process involves six fundamental mathematical abilities, namely the ability to communicate, mathematize, represent, reason and express ideas, and to use problem solving strategies appropriately. The importance of the ability of mathematical literacy is not relevant to reality.

From the results of observations of students 'mathematical literacy abilities, the average level of student mastery of students' mathematical literacy abilities was $37.4 \%$. Based on Table 1.1 above, it is concluded that the level of student mastery of students' mathematical literacy abilities is still in the low category.

The lack of communication skills and mathematical literacy of students is caused by several factors including: 1) The lesson plans made by the teacher do not include the steps of the model activities, methods, or approaches that the teacher will use when learning that can improve students' mathematical thinking in the process learning. 2) The absence of learning devices that are in line with expectations, namely learning devices that can develop students' mathematical communication skills. Conditions in the field of students only use textbooks and Student Activity Sheets (LKPD) distributed by the government. without making teaching materials that can improve students' mathematical abilities. 3) In addition to textbooks and LKPD. Based on the description above the existence of a learning device is very necessary because through the learning device the teacher will be easier to carry out learning and students will be more helped in learning. In addition, efforts to improve student learning in Mathematics in order to create better changes require a mathematical learning approach to treat mathematical communication problems and mathematical literacy of students, while what is meant by researchers is a realistic mathematical approach (PMR).

So it can be concluded that the learning tools and learning approaches need to be linked to the objectives of the learning process to be achieved, namely to see students' mathematical literacy and communication skills in solving various problems in mathematics.

According to Soedjadi (Iis Holisin 2007), the Realistic Mathematical Approach is basically the use of reality and the environment understood by students to facilitate the process of learning mathematics so as to achieve the goals of mathematics education better than in the past. According to Zulkardi (2006: 4), the Realistic Mathematical Approach Theory consists of five characteristics, namely: 1) the use of real context as a starting point in learning mathematics, 2) the use of models that emphasize informal solution before using formal methods or formulas, 3 ) linking various topics in mathematics, 4) the use of interactive methods in learning mathematics, 5) Appreciating the variety of answers and contributions of students.

In PMR, the real world is used as a starting point for the development of mathematical ideas and concepts. The real world is something outside of mathematics, like subjects other than mathematics, or our daily lives and the environment around us. (Blum \& Niss, 1989) and De Lange (1996) (Tatak Handaya Kurniawan, 2016) define the real world as a concrete real world, which is conveyed to students through mathematical applications. That's how we understand the process of learning mathematics that happens to students, which occurs in real situations.Referring to the characteristics and principles of the Realistic Mathematical Approach (PMR), The 
following are PMR steps used in the learning process (Ningsih 2014 series) namely; 1) Understanding contextual problems, 2) explaining contextual problems, 3) solving contextual problems, 4) comparing and discussing answers, 5) concluding.

Based on the explanation that has been described above, the researcher would like to research on "Development of Mathematics Learning Devices Based on Realistic Mathematical Approaches to Improve Mathematical Communication Skills and Mathematical Literacy Abilities of SMP Negeri 5 Torgamba Students".

\section{RESEARCH METHODS}

This type of research includes research and development research that aims to find out the improvement of students' mathematical communication skills and mathematical literacy abilities of students based on a realistic mathematical approach developed. learning tools developed in this study were teacher books, student books, LKPD, and RPP based on realistic mathematical approaches. This research was conducted at SMP Negeri 5 Torgamba. located on Pinang Damai strase, Torgamba District, Labuhanbatu Selatan Regency in the odd semester of 2019/2020. The population of this research is the whole class VIII of SMP Negeri 5 Torgamba by taking a sample of 2 classes with 60 students.

\section{RESULTS}

Based on the research results of several expert validators, mathematics learning tools with realistic mathematical approaches are declared to be very valid materially, construction and language which will be shown in table 4.1 below :

Table 4.1 Summary of Results of Validation of Learning Tools by Experts

\begin{tabular}{|c|c|c|c|}
\hline No & Judged Object & Average value Total Validity & Validation Level \\
\hline 1 & Learning Implementation Plan & 4.5 & Valid \\
\hline 2 & Student Worksheet & 4,4 & Valid \\
\hline 3 & Student Book & 4.5 & Valid \\
\hline 4 & Teacher's Book & 4.5 & Valid \\
\hline
\end{tabular}

Effectiveness Analysis Learning Tools With Realistic Mathematics Approach in Trial I

Based on the results of the trial I obtained that the learning tools developed based on a realistic mathematical approach have not yet reached effectiveness in learning. This is indicated by showing that the classical mathematical communication ability of students on the posttest results is $77 \%$, and the average mathematical literacy ability of students on the posttest results is $58 \%$.

Effectiveness Analysis Learning Tools with Realistic Mathematics Approach in Trial II

Classical completeness of the results of students' mathematical communication skills at posttest II trial amounted to $93 \%$ and classical completeness of the results of students' mathematical literacy abilities at posttest II trial $87 \%$. In accordance with the criteria of completeness of student learning outcomes in a classical way, ie at least $85 \%$ of students who take the test of communication skills and mathematical literacy abilities of students are able to achieve a minimum score of 65 . Thus, the results of the posttest communication skills and mathematical literacy abilities of students meet the completeness of classical .

Description of the Improvement of Mathematical Communication Skills and Mathematical Literacy of Students

The results of the analysis of the improvement of students' mathematical communication skills in trials I and II showed that the average mathematical communication skills of students in the posttest results in the first try was 72.50 increased to 79.24 in the second trial. Thus it is known that an increase in the average value of students' mathematical communication skills by 6.74 .

The results of the analysis of increasing students' mathematical literacy abilities in trials I and II showed that the average mathematical literacy abilities of students in the posttest results in the first trial was 68.87 , increasing to 74.55 in the second trial. Thus it is known that an increase in the average value of students' mathematical literacy ability is 5.68 .

Analysis of Differences in Mathematical Reasoning Ability and Realistic Mathematics of Students Between Students Given Learning Based on a Realistic Mathematics Approach and Ordinary Learning.

The average value of the mathematical communication ability of the class of Mathematical Realistic Approach is 79.24 and the average value of the mathematical communication ability of ordinary learning classes is 68 so there is a difference of 11.24. Significantly significant (sig. 2-tailed) results obtained with the t-test were 0,000 . Because the significance value is smaller than $0.05, \mathrm{Ha}$ is accepted, so it can be concluded that there are differences in communication skills between learning tools based on realistic mathematical approaches that are developed with ordinary learning in SMP Negeri 5 Torgamba. Likewise with the mathematical literacy abilities of students obtained on averagethe class in the realistic mathematics approach is 74.55 and the average value of the mathematical literacy ability of the ordinary learning class is 62.00 so there is a difference of 12.55 .Significantly 
significant (sig. 2-tailed) results obtained with the t-test were 0.025 . Because the significance value is less than 0.05 , Ha is accepted, so it can be concluded that there are differences in students' mathematical literacy abilities between learning tools based on realistic mathematical approaches that are developed with ordinary learning at SMP Negeri 5 Torgamba.

\section{REFERENCES}

Hasratuddin. 2015. Why should you study mathematics? Medan: Prime Publishing Hodiyanto. 2017. Mathematical Communication Skills in Mathematics Learning. Vol. 7 no. 1: 2088-687X.

Holisin iis. 2007. Realistic Mathematics Learning. Vol 5. No. 3: 14125889

NCTM (2000). Principles and Standards for School Mathematics, Reston, Virginia

Ningsih, Seri. 2014.Realistic Mathematics Education: Alternative Models of School Mathematics Learning. Vol. 01 No. 2. IAIN Antasari.

OECD (2016). PISA 2015 Assessment and Analytical Framework: Science, Reading, Mathematic and Financial Literacy. Paris: OECD Publishing

Supandi, Rosvitasari Nur, Kusumaningsih 2017. Improved mathematical written communication skills through think-talk-write strategies. Vol 1, No 2, 227-23

Wardono Rosyida Isnaini, Mulyono. 2018. Mathematical Literacy Ability and Student Learning Independence in Geogebra Assisted Rme Learning Model .. Vol 1. Semarang State University

Zulkardi, 2006.Designing Your Own Math Contextual Questions. Palembang Sriwijaya University. 